\title{
CONTRADICTIONS OF THE IMPACT OF TOURISM ON THE SOCIO-SPATIAL DEVELOPMENT OF BELGRADE
}

\author{
DOI: https://doi.org/10.18509/GBP210323ms \\ UDC: 338.485:304(497.11) \\ 338.482:311.2(497.11)"2000/2015"
}

\section{Vesna Miletić-Stepanović}

Faculty of Geography, University of Belgrade, Serbia

\begin{abstract}
The aim of paper is sociological analysis and articulation od the influence that tourism exerts on social development and quality of life in Belgrade. Belgrade is becoming the city where two different and contradictory functions collide - functions of place of (permanent) residence (residential, educational, health, production, trafffic) and tourist function of tourist brand. In this way, two diffrenet poulation groups are formed - the population to which Belgrade is a place of residence, and tourists who spand their leisure time there, at the same time and in the same area. The tourist function gradually subordinates the rest, the city becomes a space for tourist consumption, a city of tourist spectacle and tourist pseudo-vents, and generates the production of social space adapted and subordinated to needs global tourism market. Starting hypothesis: the development of tourism in Belgrade is part of the pattern of socio-spatial de-development of the semi-periphery, and has ambivalent consequences - although it enhances economic growth, it also intensifies social destruction and negative structural changes such as sociopathological phenomena (alcoholism, gambling) and sexist spectacles (strip clubs) as a systemic regularity, which represents a subordinate, heteronomous and institutionally invisible space. The city is implementing a promotion strategy as a place suitable for business and entertainment. A space is produced that is based on sexist stereotypes, vulgar sexual allusions that are mostly misogynistic. The consequence of the restructuring in the area is a decrease in the use value of the area of Belgrade. In the area of the Belgrade metro, there is a contradictory - fragmented heteronomous semi-peripheral spatialfunctional structure, which enhances the development of the underdevelopment of the semi-periphery and the flexible accumulation of global multinational capital [16]. Flexible accumulation of capital through the tourism industry acquires a specific spatial and gender dimension, and cities have a special logic of spatial organization and content: there is an acceleration of commodification - subordination of the use value to the market, so that the urban space of Belgrade is treated as a turnover value on the tourist market. Sources of data: Data from primary and secondary sources.
\end{abstract}

Keywords: Belgrade, social development, tourist market

\section{INTRODUCTION}

Due to its rapid development and impact on the global and national economy, tourism today is considered a development interest. Moreover, tourism is the most massive way of spending leisure time in the modern world, in which there is a global explosion in the number of tourists. The World Tourism Organization is committed to sustainable and inclusive tourism, defining it as resource management by meeting economic, social and aesthetic needs while maintaining cultural integrity, essential ecological processes, 
biological diversity and life support systems, creating well-being for society as a whole, taking into account the needs of tourists and their hosts [22]. However, the singularities of society have a great influence on the characteristics of tourism.

According to the Development Strategy of Belgrade, the principle of strategic development is competitiveness, the increase of financial resources, fiscal revenue collection, creating an environment for investment. A series of negative effects of uncontrolled commercialization of urban space of reduced quality and volume, the provision of public services and space, and increase of socio-spatial inequalities [19].

The pressure of international institutions and capital, within the strategy to attract investment, causes strengthening of the entrepreneurial capacity of local government, but at the same time it does not encourage those mechanisms of urban policy that are important for protection of public interest and vulnerable populations [19]. Belgrade development strategy also emphasizes economic goals, European integration goals and attraction of foreign capital, while long-term social goals are systematically neglected [16].

\section{THEORETICAL APPROACH}

In structural terms, Belgrade is a semi-peripheral city within the capitalist world-system. Semi-peripheral cities function according to specific principles, which are not the same as the multinational capital center. On the semi-periphery of global capitalism, there is a specific pattern, which in theory is defined as de-development or the development of underdevelopment. This process intensifies social destruction, creates a new, destroyed social structure, which increases poverty, social inequality, structural and chronic unemployment, lowers the quality of everyday life, establishes the dominance of the "survival economy", "dropout" of large population groups from the social and health care system [6]. It is, therefore, a negative social change, which implies a negative structural change of the periphery, which in economic terms can be described as an underestimation of human, institutional and infrastructural capital [14] .We define social development as a set of structural changes that are undertaken in order to find coherent and lasting solutions to problems, refers to changes related to improving the quality of people's lives, creating opportunities to meet people's needs, strengthening social security, improving the conditions of production and reproduction of life and prevention and suppression of social problems. According to the Belgrade Development Strategy, like most cities whose position within the global system is relatively unfavourable, it is oriented towards the global market and the interests of multinational corporations [23], i.e., towards the economic growth. Strategies that encourage economic growth as a goal and not as a tool that should ensure social development and better quality of life and realization of citizens' rights can rightly be called reductionist and functionalist, and defined goals can be said to be illegitimate and politically incorrect. Removing obstacles to market development and achieving competitiveness is often reduced to deregulation [19].

Long-term goals, such as social development, are neglected. Such a development plan generates a chaotic model of development [20], "neglecting the social dimension" [19]. "Negative social consequences of restructuring" [19], as well as radical differentiation of economic, social and spatial structure [19]. The result of such processes is the neglected social dimension [19] and a radical differentiation of the economic, social and spatial structure [19] . Of particular importance for this paper is the fact that the city uses the "strategy to promote urban spaces for consumption as places suitable for business and entertainment" [19], which produces negative effects - uncontrolled commercialization 
of urban space, reduced quality and volume of public services and spaces, and the increase of socio-spatial inequality [19]. Theorist Guy Debord, who criticized the spectacle in modern society, stated that it is the spectacle itself that creates consumerism. The spectacle is encouraged as passive entertainment, instead of active leisure time, and alienation is also associated with passive entertainment. Moreover, the spectacle produces pseudo-needs [9] .The role of the spectacle is to cause alienation, which encourages economic expansion, whereby the consumer becomes a consumer of illusions, which emphasizes the degradation of use and the triumph of market value [12] .

At the beginning of the 21st century, it is fair to say that the sphere of tourism is largely spectacularized. Neo-Marxism emphasizes the contradictions that arise between economic growth and social development, which post-socialist cities are especially prone to. This particular thesis is the starting point of this paper.

\section{Hypothetical framework}

Capital has alienated labour from workers, but it has also alienated leisure time from citizens, all with the aim of accumulating and producing capital under the pressure of globalization. The structural transformation of society has produced a new role for tourism within the spectacle society. In modern society, the conditions of production, social relations, social and spatial structure have changed. A new form of production was generated - intangible production, and a new form of control - control through the cultural and tourism industry. The tourism industry, as well as the alcoholic beverage industry, the gambling industry and the sex spectacle industry, accumulates capital through alienation in tourism, during free and leisure time. New spaces of alienation and accumulation of capital, spaces of consumption of tourism contents, tourist manifestations, tourist tours were also generated. The consequence of such economic growth is the generation of social issues, addiction, misogyny.

Also, there is a decrease in the use value of Belgrade. Within the Belgrade metropolitan space, there is a contradictory - fragmented heteronomous semi-peripheral spatiofunctional structure, which enhances the development of the underdevelopment of the semi-periphery and the flexible accumulation of global multinational capital [16].Urban space of semi-peripheral Belgrade and the tourist space cannot be understood outside the capitalist relations that produce it, because the organization of the tourist space is a product of the flexible geography of capitalist production, i.e. "Geographical Marginality". The urban contradiction of Belgrade includes the fragmentation of the social space of Belgrade into, on the one hand, commercialized - touristized, and on the other hand, institutional, while developing the commercial, tourist business space of the post-Fordist New Economy. Flexible accumulation of capital through tourism industry acquires a specific spatial and gender dimension, and cities get a specific logic of spatial organization and content. There is an acceleration of commodification - subordination of the use value to the market value, so the urban space of Belgrade is treated as turnover value on the tourism market.

A space is produced that is based on sexist stereotypes, vulgar sexual allusions that are mostly misogynistic; commodification of urban space, within the tourism field, endangers the function of leisure time, violates gender equality and causes violence against women, and causes a patriarchal and anti-civic space based on misogynistic understanding of gender roles in society. Pornography in tourism is a direct tool for exploitation, subjugation and humiliation of women. 


\section{Indicators}

Indicators of economic growth (tourism capacity, increase of tourist arrivals and overnight stays, income from tourism, foreign exchange inflow from tourismSocial risk indicators: 1. indicators of the development of the gambling industry (institutionalization of the gambling industry in Serbia, assessment of the share of gambling industry income in total tourism revenue, assessment of income from the gambling industry, gambling industry network: gaming house - betting house - casino, number of employees in the gambling industry; negative effects of gambling); 2. indicators of alcoholism in tourism (alcohol consumption, alcoholism and diseases; tourist events, tours and games that promote fast drinking through entertainment); 3. network of facilities where sex spectacles are organized. Data sources: Data from primary and secondary sources. Data from primary sources are original, directly and first-time collected data for the purposes of studying this issue. Data from the following institutions were used: the Statistical Office of the Republic of Serbia, the Tourism Development Strategy, the Belgrade Development Strategy, the tourist organization of Serbia, and the research on the tourism economy. Data collected indirectly - data available on internet presentations.

The collection, processing, analysis and synthesis of data was performed by the author of the paper during January 2021.

Data analysis methods: analysis of data from primary and secondary sources, as well as critical data analysis.

\section{RESULTS AND DISCUSSION}

\section{Tourism industry}

Being a very dynamic branch of economy worldwide, the tourism industry is compatible with Belgrade's efforts to "be competitive with European capitals" [21], whereby this branch of economy is experiencing growth in Belgrade as well.

Tourism is a segment of the aspiration of the city of Belgrade to "be competitive with European capitals" [23], and the tourism industry of Belgrade is perceived as an emerging industry.

\section{Tourism and accomodation capacity}

Data from three different sources are used to describe the above capacity:

- According to the data of the Business Registers Agency, the Ministry of Finance and Economy and the Secretariat for Economy and Tourism, over 5,500 companies and entrepreneurs operate in the field of tourism and accommodation in the area of Belgrade. As of December 31, 2012, the accommodation and tourism infrastructure was as follows: over 5,500 companies and entrepreneurs operate in the field of tourism and accommodation in the area of Belgrade. The infrastructure includes 45 hotels, 4 of which are 5-star hotels, 18 of which are 4-star hotels, 14 are 3-star hotels, 8 are 2-star hotels and 1 is 1 -star hotel; there are also 16 hotel garnis, 9 of which are 4-star hotel garnis, 5 of which are 3-star hotel garnis and 2 are 2-star hotel garnis; there are also 4 dependances, 1 motel, 1 camp. As many as 475 units of categorized private accommodation, which have 1,001 beds, around 130 uncategorized accommodation facilities (inns, boarding houses and around 80 hostels), 271 travel agencies and around 2,500 restaurant-type accommodation facilities (TOB estimate).

- According to the Development Strategy, Belgrade has (as of 2015) 142 accommodation facilities, 7,846 rooms and over 15,344 beds. There are mostly hotels (52) and hostels (35 
facilities), followed by hotel garnis (29) and inns (15). However, hotel accommodation in Belgrade makes up only $16.8 \%$ of hotels in Serbia. Based on the number of beds, hotels in Belgrade make up 27\% of the total capacity of beds in Serbia. From the aspect of inflow of foreign tourists, former Yugoslav republics (Montenegro, Croatia, Slovenia, Bosnia and Herzegovina) have the highest inflow, followed by Bulgaria, Greece, Hungary, Italy [21]. According to the tourism development strategy between 2016 and 2025, as of December 2015, Serbia had a total of 358 hotels, motels, boarding houses and tourist resorts and 30,417 of beds. The hotel market in Belgrade is as follows: in 2016, there were 86 hotels, 51 of which were hotels, 34 hotel garnis and one apartment hotel. Belgrade has every fourth categorized hotel (86), every third accommodation unit $(6,331)$ and almost every third bed $(9,193)$ [7]. The analysis of income from tourism shows the following: Revenue from tourism in 2017 in Serbia amounted to 1.2 billion euros (almost 1.5 billion dollars), and the capital earned about 750 million from it, which is around $60 \%$ of total revenue, according to the data available to the TOB, and according to the data from the $\mathrm{NBS}^{9}$. The total foreign exchange inflow from tourism in 2015 amounted to USD 1,048 million. Between 2007 and 2015, foreign exchange inflows from tourism increased by $97.4 \%$, with an average annual growth rate of $108 \%$.

\section{Tourist arrivals and overnight stays}

According to research on tourist arrivals and overnight stays in Belgrade (Table 1), there has been an evident increase in foreign tourist arrivals and overnight stays after 2000 [15]

Table 1. Tourist arrivals and overnight stays in Belgrade.

\begin{tabular}{|l|l|l|l|l|l|l|}
\hline & Tourist arrivals & Overnight stays \\
\hline Year & Total & Domestic & Foreign & Total & Domestic & Foreign \\
\hline 2000 & 795817 & 707340 & 88477 & 1418188 & 1204302 & 213886 \\
\hline 2005 & 674785 & 397677 & 277108 & 1366337 & 775754 & 590583 \\
\hline 2010 & 618454 & 223046 & 395408 & 1319629 & 509807 & 809822 \\
\hline 2015 & 740957 & 143223 & 597734 & 1584849 & 366458 & 1182391 \\
\hline \multicolumn{7}{|c|}{ Source: [15] } \\
\hline
\end{tabular}

Based on studies on tourist arrivals and overnight stays in Belgrade (Table 1), a significant increase in foreign tourist arrivals and overnight stays can be seen, which would be the primary goal after 2000 [15]. Namely, as the table shows, there were 88,477 foreign tourist arrivals in 2000, while already in 2005 that number increased about three times and reached 277,108. It kept growing and in 2010 this number amounted to 395,408, while in 2015 there were over half a million arrivals - 597,734 to be exact. According to the data by the Statistical Office of the Republic of Serbia (Trends), out of a total of $4,750,000$ overnight stays in 2019, Belgrade had one quarter or 1.1 million, whereby the majority of visitors were foreign tourists $(84.5 \%)$ of the total number of overnight stays: only mountain resorts $(1,300,000)$ had more overnight stays, spa resorts had the same number of overnight stays as Belgrade - 1,100,000. However, there is one difference - in mountain and spa resorts, the vast majority of overnight stays were realized by domestic tourists - in the mountains $84.4 \%$, in spas $87.9 \%$. The remaining $1,250,000$ overnight stays were allocated to other tourist destinations $(750,000)$, Novi Sad $(250,000)$ and other destinations $(250,000)$.

\footnotetext{
${ }^{9}$ http://www.politika.rs/sr/clanak/395271/Beograd/Od-turizma-zarada-oko-750-miliona-evra
} 


\section{Pathological phenomena and addiction as a segment of the tourist industry}

Attracting capital and creating an investment environment [23] has also attracted to Belgrade the capital that is accumulated through the sale of alcohol, gambling and striptease spectacles

\section{Alcoholism}

Estimates by WHO show that around 2 billion people worldwide consume alcoholic beverages, 76.3 million of whom have been diagnosed with alcohol abuse or dependence [23]. As a negative effect of these habits, suicides occur, as well as unplanned and unprotected sex, unplanned pregnancies and an increased risk of HIV infection, sexual abuse: around 183,000 rapes and sexual assaults, 197,000 robberies, 661,000 severe assaults and 1.7 million attacks each year [8]. Europe is also seeing an increase in suicides, homicides and other alcohol-related accidents [24], including the connection with more than 60 types of diseases and injuries [24]. In developing countries with low mortality rates, alcoholism is the leading risk factor for diseases and it is the third largest risk factor in developed countries [24]. The social consequences relate to the "connection with poverty and malnutrition" [24].

According to the Institute for Mental Health, alcoholism is the most wide-spread addiction in Serbia and, after depression, it is a mental disorder that contributes the most to global disability. "The number of alcohol-induced disorders represents $10.8 \%$ of the total number of diseases in the region" [11] .One third of the adult population consumed alcohol during 2006: around 4\% of the adult population is at risk of "heavy drinking", with a significantly higher percentage of men $(5.7 \%)$ than women $(0.4 \%)$ [11], according to WHO, European research on drug and alcohol use among young people [13].

Alcoholism is primarily the habitual behaviour of men. In the twelve months preceding the European research on drug and alcohol use among young people, $82.1 \%$ of men and $62.4 \%$ of women consumed alcohol; excessive drinking once a week or more often occurs in $6.7 \%$ of men and $0.6 \%$ of women; risky patterns of alcohol abuse are present in $22.1 \%$ of men and $4.6 \%$ of women; harmful alcohol use is associated with $10.6 \%$ of men and $1.7 \%$ of women.

Intoxication (strong influence of alcoholic beverages, which includes inability to walk, difficulty speaking, vomiting, inability to remember past events) [13] is present in young people - at least once in their lives it happened to $51.8 \%$ of young men and $33,8 \%$ of girls. "Binge drinking" of excessive drinking (excessive drinking episode, which occurred within a short period of time) occurred to as many as one third of students, significantly more young men, who had five or more drinks in a row one month prior to the study [13]. The results of the National Survey on Lifestyles among Serbia Population - Use of Psychoactive Substances and Gambling [12] show that alcoholic beverages are the most common psychoactive substance used: in the population between 18 and 64 years of age, in the last 12 months as many as $70 \%$ consumed alcohol [12]; the majority have beer [12]; as much as $50.3 \%$ of alcohol is consumed by $7.5 \%$ of consumers [12] ; the average amount of alcohol consumed is 6.5 times higher in men than in women [12]. The research estimates that excessive drinking (1.5 1 of beer, 0.61 of wine, 0.181 of hard liquor, on a single occasion at least once a week or more often in the past 12 months) is consumed by $3.7 \%$ of the population, mostly men. Therefore, it is estimated that there are 580,000664,000 high-risk alcohol consumers, three quarters of whom are men; harmful drinking is present in 25,700-318,000 people, most of whom are men [12]. Negative effects of alcohol use (at work, studies, in private life, in traffic) exist in $10 \%$ of the population within the last 12 months. This figure is much higher when it comes to the negative effects 
caused by someone else's drinking - almost every other survey participant experienced such negative effects [14].

Part of tourism marketing includes open advertising of alcohol-related events, such as Wine Routes, Beer fest Belgrade, Serbian Wine Festival Lazarevac [18]. In Belgrade, there is an event that promotes beer - Beer Fest Belgrade: the current advertisement for this festival reads - "This year we get an ID card". Namely, the festival has existed for 18 years [18]. Tourist tours, which offer "Binge drinking" through entertainment are organized under the name pub crawl (or bar crawl) or more freely speaking - alcohol excursions (organized drinking while visiting several bars-pubs over the course of one night) [18]. In Serbia, after 2000, pub crawl is organized in Belgrade - Belgrade Pub crawl, as part of European tours, it has a website, and is advertised as part of the tourism identity of Belgrade, or even as one of the walking tours in Belgrade. Part of tourism marketing are alcohol games, ("Drinkopoly" - similar to the game "Monopoly"; "Beer pong" - similar to "ping-pong"; "Don't get drunk game" - similar to the Parcheesi game; "Magic word" and "King's cup" [18].

\section{Gemblification of tourist space}

The development of Belgrade as a tourist city goes hand in hand with the development of gambling houses and casinos. The network of gambling houses and casinos is seen as the gemblified urban space of Belgrade, which includes specific values and norms, which produce socio-pathological phenomena which are sexist, anti-family and anti-civic. The gambling industry in Serbia was institutionalized and legalized after 2000, in the same period when the growth of foreign tourist arrivals began. Called the Games of Chance Organization, organizing gambling is treated as a type of entrepreneurship, regulated by the Games of Chance Act from 2004. The fact that the Directorate for Games of Chance was established within the Ministry of Finance, which also has an electronic register, speaks for itself about its status in the country. According to the data from this directorate, as of 14/01/2020, there are 31,305 slot machines in Serbia, and 2,110 betting sites. According to the Gambling Organizers' Association, Serbia is the 19th in Europe in terms of the number of legal betting houses in relation to the number of inhabitants. Data on gambling tourism revenue are scarce, but there are estimates that it was about $\$ 500$ million in 2015 [17].

Number of employees in this field is very high: the data by the Statistical Office of the Republic of Serbia from January 31, 2020 show that as many as 10,616 people are employed in the field of betting and gambling, which is, compared to other sectors, significantly more than in the Serbian oil industry, in coal industry, in libraries, archives, museums and galleries, in creative, artistic and entertainment activities; almost twice as many employees as in Smederevo Ironworks, three times more than in Srbijagas; same number as employees as is the case in scientific research and development field and in mining. The number of employees in gambling industry is like one third of the employees in agriculture, in the exploitation of oil and gas. Apart from the number of employees, its structure is also very specific: as many as one third have a university degree, with hundreds of IT professionals with the highest references. Due to the strong connection between gambling and betting with program support software, it happens that talented students of analytics, statistics and software engineering are awarded scholarships [17]. There is also cooperation with marketing experts. The network of companies that organize games of chance in Belgrade consists of as many as 525 facilities owned by 24 companies. These facilities are located throughout the entire city, and are often located near schools [17] . Most of them are gaming houses and betting houses, but there are also five Casinos 
in Belgrade (Grand Casino Belgrade, Aleksandar, Admiral Klub, Fair Play, Hotel Slavija), whose target group are high-income individuals. Fair Play Casino was the first one established, back in the time of transition and the turbulent 1990s (1993) at Terazije. Admiral Klub Casino was founded in 1994 in Belgrade. It has casino table games for and slot machines. With the conversion of space purpose, the former Hotel Jugoslavija, located in the center of Belgrade and built during the youth work actions, is now the Grand Casino. The Grand Casino organizes spectacular events, such as a poker tournament, several times a year. It is very paradoxical to organize a tournament during the holiday of solidarity, which is related to the struggle of women for equality - a tournament for women, which is held on March 8th. The Carnival is organized every year as well, with international cuisine dishes, and a music program with some of the most popular musicians performing (Lena Kovačević, Bojana Stamenov, Bijelo Dugme Band for the 40th band anniversary). They organize luxury events such as:

- old car exhibition ("24 Hours of Elegance - Concours d'Elegance and Luxury Salon", from Southeast Europe and Serbia) under the patronage of the Auto Museum Belgrade;

- -exhibition of luxury items (Luxury Salon) with the participation of the owner and editor of MONSIEUR [1] magazine, directors of multinational companies (textile industry (fashion houses COSTUME NATIONAL [2], SCIAMAT [3], CERRUTI), representatives of the international distributor of luxury alcoholic beverages (Pernod Ricard) [4], representatives of the tobacco industry Tobacco International (JTI), automotive industry (Grand Motors);

- an exhibition of over 100 diamonds (including a heart-shaped yellow diamond worth half a million euros) by the Israel Diamond Center (IDC), whereby the exhibition was opened by members of the global political and economic elite personally - the Israeli ambassador and the company's founder

The former Hotel Slavija, worked as the Casino of Hotel Slavija - Havana Gambling covering as much as $600 \mathrm{~m} 2$ of space. The opening ceremony was attended by playboy girls, as well as the cultural elite - famous TV hosts and artists. On the other hand, gambling is defined as a growing mental health condition and gambling massively destroys the health of the population. The Institute of Public Health estimates that there are 14,000-33,000 pathological gamblers in Serbia, with every third high school student being a gambler. According to the data by the Day Hospital, gambling produces poverty (risk of homelessness, falling into a debt with usury rate), collapse of marriage and family, violence against women and children. However, we would here emphasize that the problem is not perceived as socially and systemically caused, it is rather medicalized and psychologized. A protocol on cooperation was signed between the Grand Casino and the Belgrade City Assembly: an SOS center and a telephone line intended for pathological gamblers were established. Data on gambling as a factor in attracting tourists are scarce, but they show that tourists come to Belgrade from countries where gambling is prohibited (Israel, Turkey, Greece) [17].

Strip clubs at the city centre

A segment of commercialized space includes sexist strip clubs, which consists of a dozen strip clubs [5] (Strip Club Black Rose VIP, Black Rose, Night Club Romansa, Strip Club Eldorado, Strip Club Crystal, Strip Club Moulin Rouge Exclusive, Strip Club Moulin Rouge, Strip Lotus Club, Red box, Dark Angels). This network of strip clubs makes up the sexist urban space of Belgrade, where there are misogynistic values and norms, androcentric needs and interests, and gender-discriminatory positions and roles: this 
space is based on symbolic violence against women, where they are perceived as sexual objects who should entertain men, on their sexual exploitation, humiliation and belittling. Recruitment ads can be seen on the internet presentation of these clubs, inviting female students to come and earn pocket money. All of these strip clubs are located in the central parts of the city, located in the very city center or on its very edge.

These locations are in very risky proximity to a number of national and city institutions: faculties, high schools, music schools, cemeteries, academies of sciences (Fire Station, New Cemetery, Bajlonijeva Green Market, Urban Institute of Belgrade, Embassies and consulates - consulate of Germany) as well as political institutions (National Assembly of the Republic of Serbia, Assembly of the City of Belgrade, Constitutional Court, National Bank of Serbia, National Employment Service), education institutions (secondary schools such as medical high school, Stankovic music school, Lujo Davičo ballet school), health care institutions (Clinical Center of Serbia, ER, University Children's Clinic, Institute of Rheumatology, Department of Psychophysiological Disorders, Department of Mental Health), Higher Education and Science institutions (Serbian Academy of Sciences and Arts, Faculty of Geography, Faculty of Philosophy ), Churches (Saborna crkva - The Cathedral Church of St. Michael the Archangel, St. Mark's Church, The Temple of Saint Sava, The Church of St. Alexander Nevsky, Library of the Serbian Patriarchate), cultural institutions (National Museum, National Theater, National Library of Serbia, Pedagogical Museum, Ethnographic Museum, Yugoslav Cinematheque, Slavija Theater, House of Đuro Jakšić, Monument of Gratitude to France).

\section{CONCLUSION: TOURISM PRACTICE - A TOOL TO PRODUCE GLOBAL CAPITALISM AND SOCIAL RISKS}

In accordance with the research objective, theoretical framework was developed in this paper in order to study the contradictions in tourism, in the context of critical neoMarxism theory. Moreover, a system of indicators has been defined as well. Arguments were presented that confirmed the assumption that the development of tourism in Belgrade is part of the pattern of socio-spatial development of underdevelopment semiperiphery, and has ambivalent negative effects - although it increases economic growth, at the same time it intensifies the processes of social destruction and negative structural change: tourism industry, alongside with the gambling industry and the sex spectacle industry, accumulates capital through alienation in tourism during free and leisure time. In that way, new spaces of alienation and accumulation of capital, spaces of consumption of tourist contents, tourist manifestations, tourist tours were also generated. The contribution of this paper refers to the conceptualization of theoretical and hypothetical framework and indicators to study and link economic growth to the tourism industry, and to research the social risks it generates, in the form of addiction and social issues at the level of family, marriage, position of women. The potential of this paper is a positive impact on a clearer understanding of the contradictory role of tourism, entertainment and leisure on the accumulation of capital and the well-being of citizens.

Tourist capacity has increased between 2012 and 2015 (the number of hotels has doubled - from 45 to 86; the number of beds increased 15 times - from 1,001 to 15,193). Tourism revenue in 2017 was $\$ 750$ billion; while foreign exchange inflow has doubled. Tourist arrivals and the number of overnight stays of foreign tourists has increased six times between 2000 and 2015 (arrivals reached over half a million; the number of overnight stays increased from about 200,000 to about 1,200,000). However, the city's tourist offer largely includes the gambling industry, as well as events, tours and games that encourage 
extreme alcoholism, as well as strip clubs. At the same time, research by global, European and Serbian institutions show that alcoholism, after depression, contributes the most to global disability and a large number of social problems. It is estimated that the number of high-risk alcohol consumers in Serbia is between 580,000-664,000, three quarters of which are men; while harmful-problematic drinking exists in 257,000-318,000 people, most of whom are men. The gambling industry, once illegal, has been institutionalized and legalized in Belgrade since the end of the 20th and the beginning of the 21 st century. It employs a very significant number of people whose level of education is favourable and includes experts from the most modern fields.

The gambling industry operates freely in 525 facilities owned by 24 companies, with 31,305 slot machines and 2,110 betting sites, and five Casinos, which organize luxury spectacles with global fashion, alcohol, tobacco, automotive, luxury jewellery brands participating. On the other hand, gambling is defined as a growing mental health condition and it is estimated that there are 14,000-33,000 pathological gamblers in Serbia, with every third high school student being a gambler which is a worrying fact. Sexist spectacles, with a misogynistic overtone, are part of the tourist offer supported by the city, in which women are understood as sexual objects for the entertainment of men, during which sexual exploitation, humiliation and belittling of women is performed. The facilities in which this type of spectacle is performed are located in the very city center, in close proximity to the most important state and city institutions. In that way, the fragmentation of the social space of Belgrade occurs. Flexible accumulation of capital through tourism industry acquires a specific spatial and gender dimension which accelerated commodification, that is, there is the subordination of the use value to the market value on the tourism market. Commodification of urban space endangers the function of leisure time, violates health, well-being, gender equality, thus strengthening the influence of the tourism industry on the production of space subordinated to the needs of the global tourism market and the accumulation of capital during leisure and free time.

\section{Acknowledgement}

The article is financially supported by the Ministry of Education, Science and Technological Development of the Republic of Serbia

\section{DATA SOURCES:}

[1] www.monsieur.it

[2] costumenational.com

[3] sciamat.com

[4] https://www.pernod-ricard.com/sr-rs/o-nama/

[5] https://www.beogradnocu.com/galerija/striptiz-klubovi/

\section{REFERENCES}

[6] Благојевић-Хјусон, М. (2012): Жене и мушкарци у Србији: Шта нам говоре бројеви?, Програм Уједињених нација за развој, Београд.

[7] Vlada Republike Srbije- Ministarstvo trgovine, turizma itelekomunikacija (2016): Strategija razvoja turizma (SRT) 2016-2025.

[8] Dasgupta, A. (2011): The Science of Drinking: How Alcohol Affects Your Body and Mind. Rowman \& Littlefield Publishers. . 
[9] Debord, G. (1967): Društvo spektakla, Porodična biblioteka br. 4 anarhija/ blok 45 http://gerusija.com/downloads/Drustvo_spektakla.pdf

[11] Институт за јавно здравље (2008): Национални водич за алкохолизам (НВА), Београд http://www.batut.org.rs/download/aktuelno/klinicka\%20praksa/Nacionalni\%20vodic\%20alkoho lizam.pdf

[12] Килибарда Б. и др (2014): Национално истраживање о стиловима живота становништва Србије 2014 - коришћење психоактивних супстанци и игре на срећу (НИСЖ-ПСИС), Институт за јавно здравље Србије “ДрМилан Јовановић Батут", http://www.batut.org.rs/download/publikacije/Izvestaj\%20srpski\%20web.pdf

[13] Кнежевић Т. (ур), (2008): Европско истраживање о употреби алкохола и других дрога међу младима у Србији 2008 - извештај за Републику Србију (ЕИУАД), Република Србије, Министарство здравља; Институт за јавно здравље Србије „др Милан Јовановић Батут; ESPAD - The European School Survey Project on Alcohol and Other Drugs; European Monitoring centre for Drugs and Drug Addiction:

http://www.batut.org.rs/download/publikacije/ESPAD\%202008.pdf

[14] Meurs, M. and Ranasinghe, R. (2003) De-development in Post-Socialism: Conceptual and Measurement Issues, Politics and Society https://library.fes.de/libalt/journals/swetsfulltext/15749429.pdf

[15] Милетић, J. (2017): Промет туриста у Београду, у: Земља и људи, Српско географско друштво, Београд, стр. 71-75

[16] Miletić-Stepanović, V. (2019): Protivrečnosti socio-prostornog razvoja Beograda: retradicionalizacija porodice kao poluperiferni urbani habitus, Geografski fakultet, Beograd.

[17] Miletić-Stepanović, V. (2020): Gambling As The Tourist Habitus, Conference GEOBALCANICA 2020 Socio economic geography (pp 513-524)

DOI: $\quad$ http://dx.doi.org/10.18509/GBP.2020.57 https://www.researchgate.net/publication/341745275_GAMBLING_AS_THE_TOURIST_HA BITUS

[18] Miletić-Stepanović, V. (2020a): Alkoholizam kao turistički habitus Beograda, u: ur. Đorđević \& Filipović \& Marić: Lokalna samouprava u planiranju i uređenju prostora i naselja, ISBN 987-86-6283-097-5 (GF) pp. 296-302.

[19] Petrović, M. (2009): Transformacija gradova: ka depolitizaciji urbanog pitanja, Institut za sociološka istraživanja Filozofskog fakulteta - Čigoja, Beograd.

[20] Stanilov, K. (2007): "Taking stock of post-socialist urban development: A recapitulation." u: Kiril S. (ed.). The Post-Socialist City: Urban Form and Space Transformations in Central and Eastern Europe after Socialism. Dordrecht: Springer: pp. 3-21.

[21] Урбанистички завод Београда и ПАЛГО Центар (2008): Стратегија развоја града Београда (СРБГ)

http://www.beograd.rs/images/file/6942bb8d4165c5fdb13fd5b97a55af2f_1235293219.pdf

[22] World Tourism Organization UNWTO (2015): Tourism Highlight https://www.eunwto.org/doi/epdf/10.18111/9789284411900

[23] WHO (2004): Global Status Report on Alcohol. World Health Organization, Department of Mental Health and Substance Abuse, Geneva.

[24] WHO (2006): Global status report on alcohol and health. World Health Organization. https://www.who.int/substance_abuse/publications/global_alcohol_report/msbgsruprofiles.pdf 